\title{
SUSCETIBILIDADE À EROSÃO LAMINAR NA BACIA HIDROGRÁFICA DO RIBEIRÃO DOURADINHO, NO TRIÂNGULO MINEIRO
}

\author{
SUSCEPTIBILITY TO LAMINAR EROSION IN THE RIBEIRÃO DOURADINHO \\ HYDROGRAPHIC BASIN, IN THE TRIÂNGULO MINEIRO
}

\author{
João Victor Freitas Silva \\ Mestre em Geografia pela Universidade Federal de Uberlândia, Brasil \\ joaovictorfs14@gmail.com
}

Vanderlei de Oliveira Ferreira

Professor da Universidade Federal de Uberlândia, Brasil

vanderlei.ferreira@ufu.br

\section{Resumo}

Os estudos sobre suscetibilidade erosiva dos solos têm como propósito principal auxiliar na gestão territorial e no desenvolvimento de práticas e ações estratégicas voltadas ao planejamento ambiental, buscando o uso sustentável dos recursos naturais. Nesse sentido, o presente texto relata resultados de pesquisa dedicada ao levantamento da susceptibilidade natural à erosão laminar na bacia hidrográfica do Ribeirão Douradinho, no Triângulo Mineiro, na tentativa de contribuir para o direcionamento do uso e manejo dos solos, tendo em vista a necessidade de prevenção e controle dos processos erosivos. Nessa avaliação foram analisados os fatores referentes à erosividade das chuvas, erodibilidade dos solos, declividade do terreno e comprimento das encostas, conforme procedimentos propostos por Salomão (1999). Na bacia estudada, a integração dessas informações de ordem natural resultou em três diferentes classes de suscetibilidade à erosão laminar, sendo estas: muito suscetível (II), moderadamente suscetível (III) e pouco suscetível (IV). De modo geral, pode-se constatar que quase metade da área da bacia apresenta suscetibilidade moderada que, quando somada às áreas muito suscetíveis, alcançam aproximadamente $65 \%$ da área total do local estudado.

Palavras-chave: Suscetibilidade erosiva; Gestão territorial; Planejamento ambiental.

\begin{abstract}
Studies on soil erosion susceptibility have the main purpose of assisting in territorial management and the development of practices and strategic actions aimed at environmental planning, seeking the sustainable use of natural resources. In this sense, the present text reports results of research dedicated to the survey of the natural susceptibility to laminar erosion in the Ribeirão Douradinho hydrographic basin, in the Triângulo Mineiro, in an attempt to contribute to the direction of land occupation, given the need for prevention and control of erosive processes. In this evaluation, the factors related to rainfall erosivity,
\end{abstract}


soil erodibility, terrain slope and slope length were analyzed, according to the procedures proposed by Salomão (1999). In the studied basin, the integration of this information of a natural order resulted in three different classes of susceptibility to laminar erosion, namely: very susceptible (II), moderately susceptible (III) and little susceptible (IV). In general, it can be seen that almost half of the basin area presents moderate susceptibility, which, when added to the very susceptible areas, reach approximately $65 \%$ of the total area of the studied site.

Keywords: Erosive susceptibility; Territorial management; Environmental planning.

\section{INTRODUÇÃO}

Entende-se por suscetibilidade erosiva a vulnerabilidade dos terrenos em face ao desenvolvimento dos processos erosivos. De acordo com Salomão (1999) os dados de suscetibilidade refletem a estreita relação existente entre as características físicas naturais de uma determinada área.

O mapeamento da suscetibilidade à erosão laminar representa a integração dos principais fatores do meio físico que interveem no processo de erosão. Este mapeamento corresponde às expectativas da intensidade do carreamento dos solos sem levar em consideração a cobertura vegetal e a interferência antrópica (OLIVEIRA, 2004).

Os estudos que buscam apresentar dados referentes à suscetibilidade erosiva dos solos têm como propósito principal auxiliar na gestão territorial e no desenvolvimento de práticas e ações estratégicas voltadas ao planejamento ambiental, buscando o uso sustentável dos recursos naturais.

Nesse sentido, o presente trabalho teve como objetivo determinar a susceptibilidade natural à erosão laminar na bacia hidrográfica do Ribeirão Douradinho, contribuindo para nortear a ocupação dos solos, tendo em vista a necessidade de prevenção e controle dos processos erosivos.

Nessa avaliação foram analisados os fatores referentes à erosividade das chuvas, erodibilidade dos solos, declividade do terreno e comprimento das encostas, sendo a suscetibilidade determinada com base na sobreposição de tais fatores, conforme procedimentos propostos por Salomão (1999).

A bacia hidrográfica do Ribeirão Douradinho abrange áreas dos municípios de Uberlândia e Monte Alegre de Minas, na Região Geográfica Intermediária de Uberlândia, no estado de Minas Gerais, entre as coordenadas geográficas 1858'52" a 19¹5'04" de latitude Sul e de 48 $13^{\prime} 41^{\prime \prime}$ a 48 49'52" longitude a Oeste de Greenwich, tendo como principais afluentes o Ribeirão Panga e o Ribeirão Água Limpa (Figura 1). 


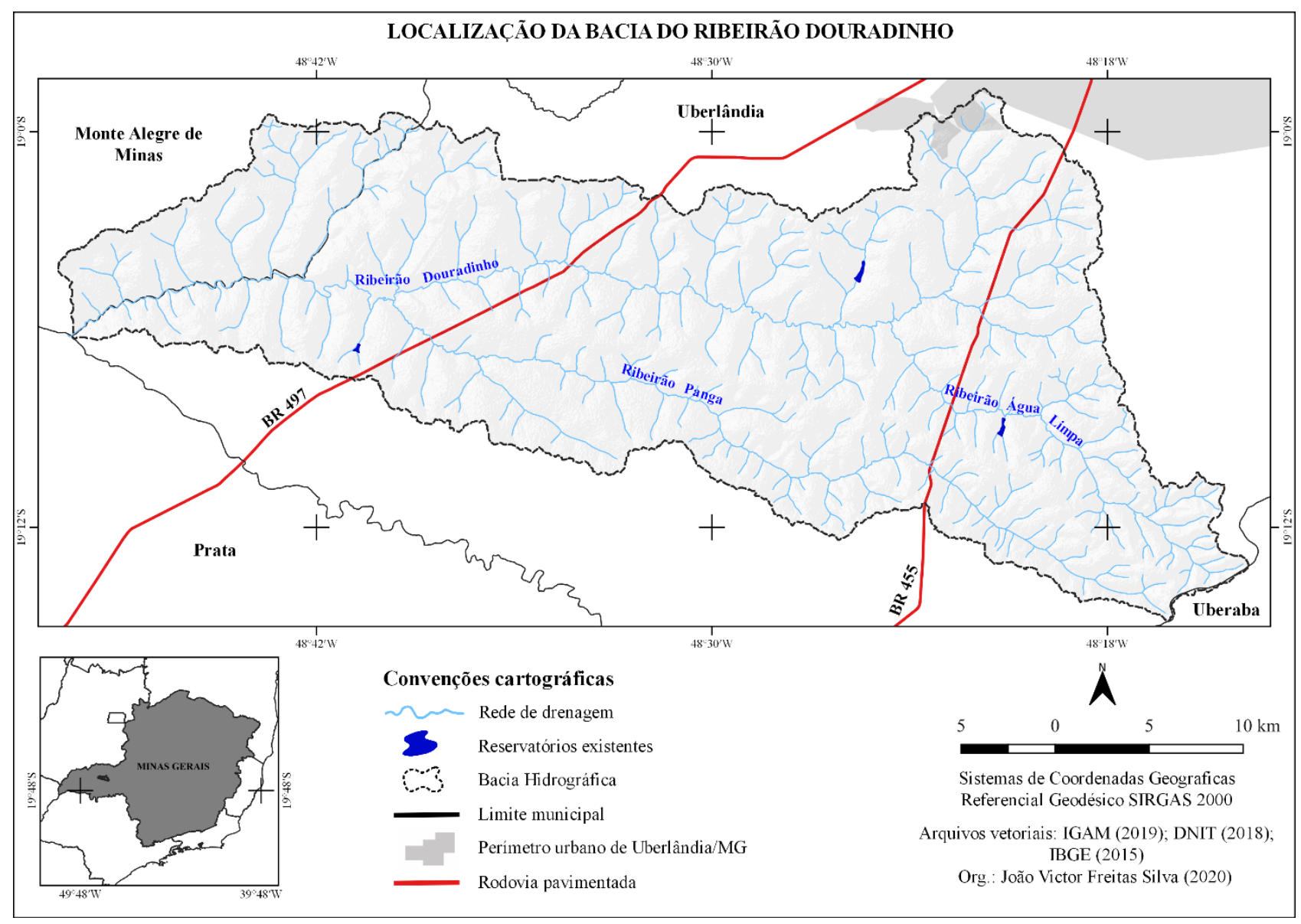

Figura 1 - Localização da bacia do Ribeirão Douradinho

Org.: Autores, 2020.

Seu canal principal percorre $65,5 \mathrm{~km}$ desde suas nascentes, localizadas no Bairro Morada Nova, na porção Sudoeste do perímetro urbano de Uberlândia, até a sua foz no Rio Tijuco. A bacia possui uma área total de $922,16 \mathrm{~km}^{2}$, sendo cortada pelas rodovias $\mathrm{BR}$ 497, no sentido Uberlândia/Prata, e BR 455, no sentido de Uberlândia/Campo Florido. No contexto regional das bacias hidrográficas, o Ribeirão Douradinho é afluente da margem direita do Rio Tijuco, que se encontra inserido na Bacia do Rio Paranaíba, na Região Hidrográfica do Rio Paraná.

\section{MATERIAIS E MÉTODOS}

Para estudar o fenômeno da erosão laminar é preciso, primeiramente, ter o conhecimento das variáveis que interferem em seu processo. Desta forma, em conformidade com a proposta apresentada por Salomão (1999), tais variáveis foram analisadas individualmente, tendo em vista a necessidade da elaboração de mapas parciais dos fatores condicionantes da erosão para a aplicação do modelo proposto. 
A suscetibilidade natural à erosão laminar foi calculada por meio do mapeamento, no software Qgis 3.4.15, e do cruzamento matricial dos dados referentes aos fatores supracitados. Cada um desses fatores resultou em determinado índice ou classe, capaz de refletir o grau de susceptibilidade ao processo erosivo.

Para a determinação da erosividade, inicialmente foi realizada a coleta de dados pluviométricos no site Portal HidroWeb, da Agência Nacional de Águas (ANA), referentes a cinco estações, sendo elas: Fazenda Letreiro; Fazenda Paraíso; Fazenda Nossa Senhora Aparecida; Monte Alegre de Minas; e Xapetuba (Figura 2).

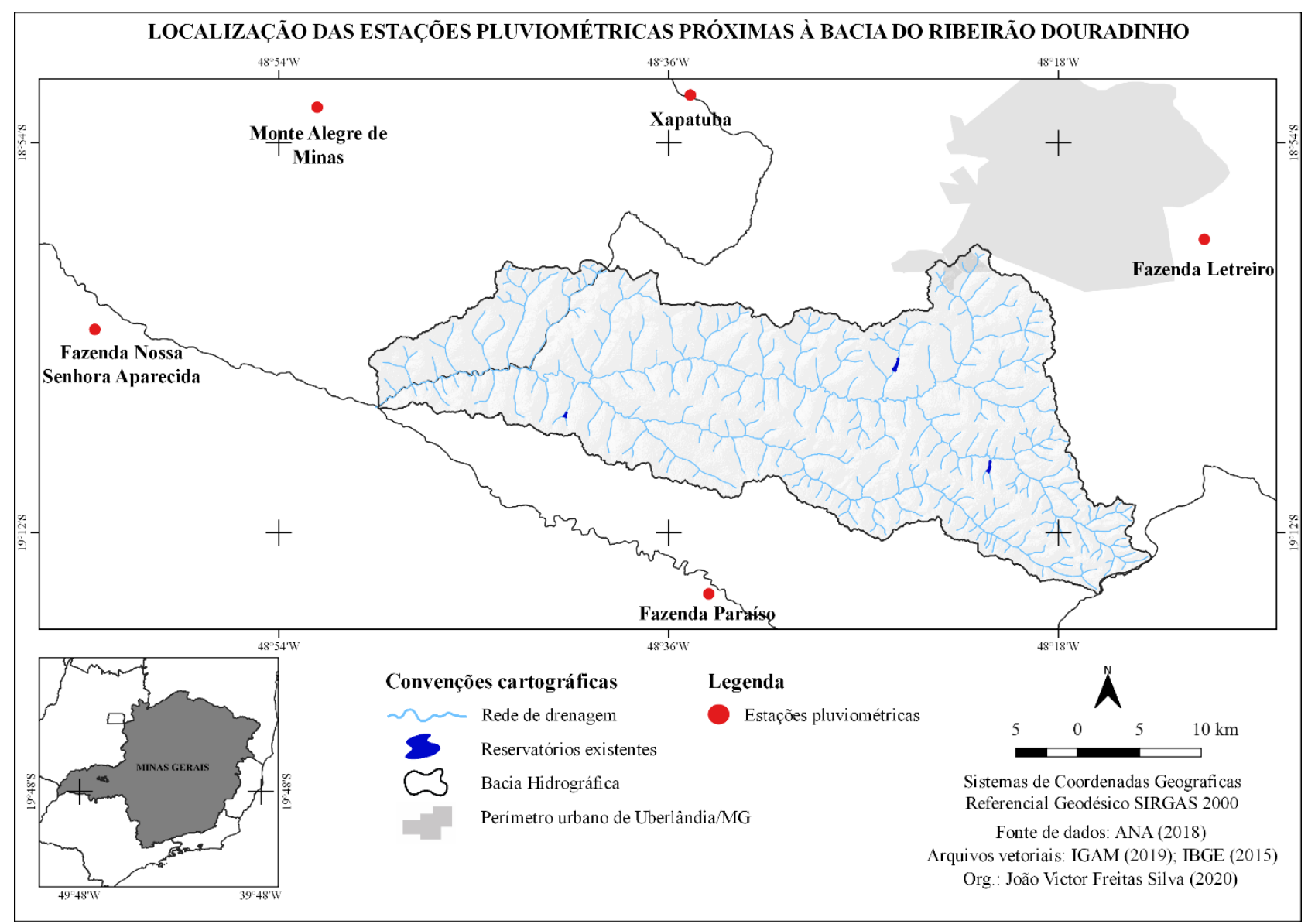

Figura 2 - Localização das estações pluviométricas

Org.: Autores, 2020.

Inicialmente foram calculados os índices de erosividade mensal para cada estação pluviométrica, baseado na aplicação da metodologia proposta por Bertoni e Lombardi Neto (1993), (Equação 1). 


$$
E I=67,355\left(\frac{r^{2}}{P}\right) 0,85
$$

Onde:

EI - índice de erosividade média mensal (MJ.mm/ha.h.mês);

$\mathbf{r}$ - precipitação média mensal $(\mathrm{mm})$;

$\mathbf{P}$ - precipitação média anual $(\mathrm{mm})$.

Por meio dos resultados dos índices mensais, foi possível realizar o cálculo da erosividade anual (Equação 2). O resultado final foi obtido através da soma dos valores das médias mensais de erosividade para cada uma das estações pluviométricas.

$$
\boldsymbol{R}=\sum \boldsymbol{E I}
$$

Onde:

$\mathbf{R}$ - Erosividade anual (MJ.mm/ha.h.ano);

EI - índice de erosividade média mensal (MJ.mm/ha.h.mês).

A classificação da erosividade na bacia seguiu o critério de qualificação dos valores proposto por Carvalho (2008) que se encontra dividido em cinco classes (Tabela 1).

Tabela 1 - Classificação da erosividade das chuvas

\begin{tabular}{cc}
\hline Erosividade (MJ.mm/ha.h.ano) & Qualificação \\
\hline$<2452$ & Fraca \\
\hline 2452 a 4905 & Moderada \\
4905 a 7357 & Moderada a Forte \\
\hline 7357 a 9810 & Forte \\
$>9810$ & Muito Forte \\
\hline & Fonte: Carvalho (2008).
\end{tabular}

A erodibilidade foi definida a partir do mapa de solos da bacia, tendo como base índices já preestabelecidos na literatura por Bertoni e Lombardi Neto (1993), Machado et al. (2009) e Mannigel et al. (2002), correspondentes às diferentes formações pedológicas.

A ponderação da erodibilidade para a área de estudo seguiu o critério da proposta elaborada por Salomão (1999) onde os índices das principais unidades pedológicas foram relativizados em uma escala de 0 a 10 e divididos em cinco classes, conforme apresentado na Tabela 2.

O fator declividade do terreno foi determinado a partir do Global Digital Elevation Model (GDEM) com resolução espacial de 30 metros, obtidos por meio de imagens do Advanced Spaceborne Thermal Emission and Reflection Radiometer (ASTER), no site EarthData da National Aeronautics and Space Administration (NASA), baseando-se na 
classificação apresentada por Salomão (1999), expressa na Tabela 3, viabilizando a sobreposição dos dados de acordo com a metodologia adotada.

Tabela 2 - Classes de erodibilidade

\begin{tabular}{|c|c|c|}
\hline Classes & Índices relativos & Unidades Pedológicas \\
\hline I & 8,1 a 10,0 & $\begin{array}{l}\text { - } \text { Cambissolos, Solos Litólicos } \\
\text { - Podzólicos abruptos, textura arenosa/média } \\
\text { - } \text { Areias Quartizosas }\end{array}$ \\
\hline II & 6,1 a 8,0 & $\begin{array}{l}\text { - Podzólicos não abruptos, textura } \\
\text { média/argilosa, e textura média }\end{array}$ \\
\hline III & 4,1 a 6,0 & - Podzólicos de textura argilosa \\
\hline IV & 2,1 a 4,0 & $\begin{array}{l}\text { - } \quad \text { Latossolos de textura média } \\
\text { - } \quad \text { Latossolos de textura argilosa } \\
\text { - } \quad \text { Terra Roxa Estruturada }\end{array}$ \\
\hline $\mathbf{V}$ & 0 a 2,0 & - Solos Hidromórficos em relevo plano \\
\hline
\end{tabular}

Fonte: Salomão (1999).

Tabela 3 - Classes de declividade apresentadas por Salomão (1999)

\begin{tabular}{cc}
\hline Classes & Declividade (\%) \\
\hline I & $>20$ \\
II & 12 a 20 \\
III & 6 a 12 \\
IV & $<6$ \\
\hline
\end{tabular}

Fonte: Salomão (1999).

O procedimento para a obtenção dos valores do comprimento das encostas foi realizado seguindo a metodologia do retângulo equivalente, apresentada por Villela e Mattos (1975). Por essa metodologia determina-se o comprimento médio através da razão entre a área da bacia $\left(\mathrm{em} \mathrm{m}^{2}\right)$ e o somatório de todos os seus cursos d'água (em $\mathrm{m}$ ), (Equação 3).

$$
L=A r / 4 \times l c
$$

Onde:

$\mathrm{L}$ - comprimento de encosta $(\mathrm{m})$;

$\mathrm{Ar}$ - área da bacia $\left(\mathrm{m}^{2}\right)$;

Ic - somatório do comprimento de todas as redes de drenagem da bacia $(\mathrm{m})$.

Para tanto, inicialmente foi efetuada, a partir dos dados do Modelo Digital de Elevação (MDE) de altitude do projeto Topodata e com o auxílio da ferramenta Terrain Analysis Using Digital Elevation Models (TauDEM), a delimitação e vetorização dos divisores de água das microbacias hidrográficas existentes dentro dos limites da área de estudo. Posteriormente, 
fez-se a sobreposição desta camada aos dados relacionados à rede de drenagem, possibilitando o cálculo do comprimento de encosta para cada microbacia, e sua distribuição em diferentes classes.

A suscetibilidade erosiva na bacia, a qual reflete as características naturais dos terrenos perante o desenvolvimento dos processos erosivos, foi definida através do cruzamento matricial e da sobreposição das informações referentes aos fatores acima citados, conforme as etapas elucidadas na Figura 3. Tal cruzamento poderia resultar em até cinco diferentes classes para a área em questão.

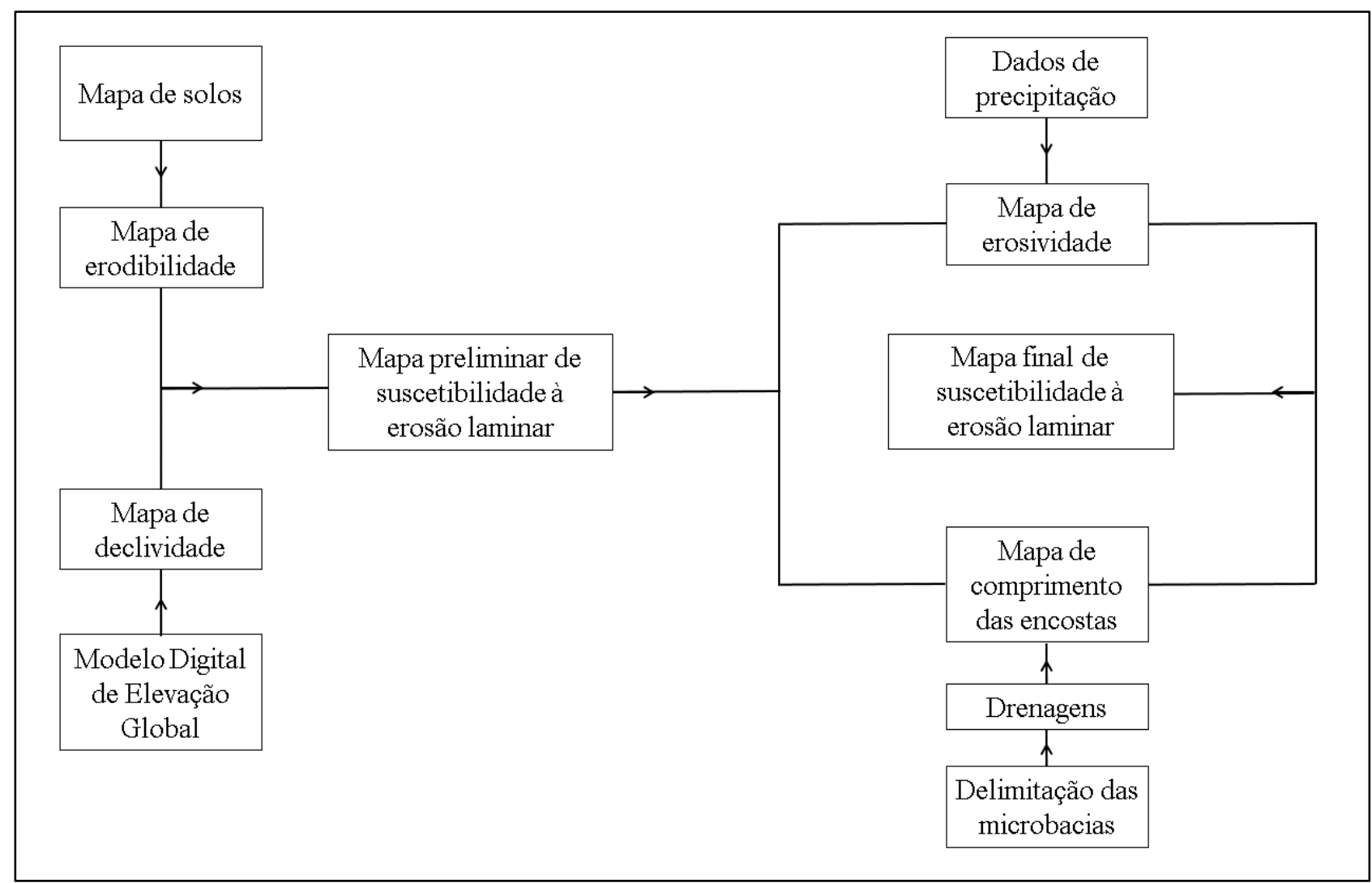

Figura 3 - Roteiro metodológico para a definição das classes de suscetibilidade à erosão laminar. Fonte: Adaptado de Salomão, 1999.

As classes preliminares de suscetibilidade foram obtidas pela integração dos dados de erodibilidade do solo e de declividade do terreno. Essa integração foi realizada por meio do cruzamento relacionando as classes dos referidos fatores, conforme os critérios apresentados na Tabela 4, resultando no mapa preliminar de suscetibilidade à erosão.

A classificação final procedeu-se através da sobreposição das classes preliminares aos dados de erosividade das chuvas e de comprimento das encostas encontrados, permitindo definir com maior precisão as áreas/classes de suscetibilidade à erosão laminar. 
Tabela 4 - Critério para a definição das classes preliminares de suscetibilidade à erosão laminar (IPT, 1990)

\begin{tabular}{|c|c|c|c|c|c|}
\hline & \multicolumn{4}{|c|}{ Declividade (\%) } \\
\hline & & $I(>20)$ & II (12 a 20) & III (6 a 12) & IV $(<6)$ \\
\hline \multirow{5}{*}{ 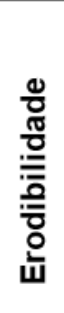 } & I & I & I & II & II \\
\hline & II & 1 & II & II & III \\
\hline & III & II & III & III & IV \\
\hline & IV & III & IV & IV & V \\
\hline & V & Não existe & Não existe & Não existe & V \\
\hline
\end{tabular}

Fonte: Salomão (1999).

Para a sobreposição aos dados de erosividade foi feita a ponderação com base na classificação proposta por Carvalho (2008), descrita na Tabela 1. As classes de erosividade propostas foram espaçadas de forma proporcional à sua intensidade visando um maior detalhamento e possibilitando uma melhor determinação dos resultados, sendo seus valores ponderados nos pesos de 0,1 ou 2, considerando o seu nível de força.

Desta forma, os pesos foram atribuídos às interseções e, posteriormente, integrados e convertidos nas classes finais. O cruzamento final dos dados para a obtenção da suscetibilidade na bacia foi realizado conforme os critérios apresentados na Tabela 5 .

Tabela 5 - Critério para a definição das classes finais de suscetibilidade à erosão laminar

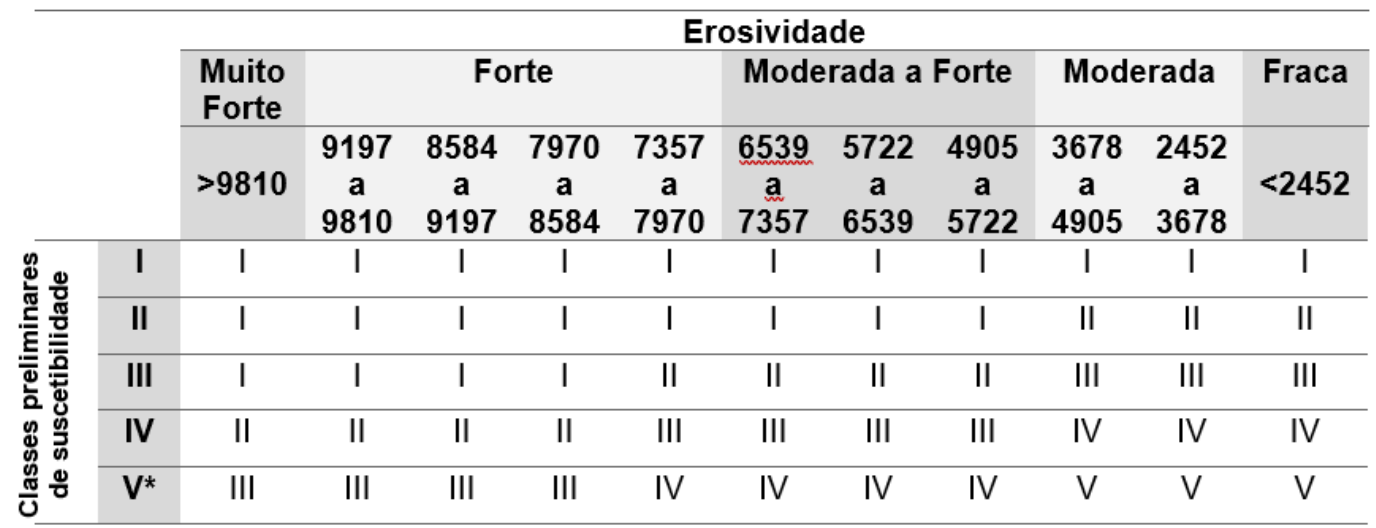

Fonte: Adaptado de Carvalho (2008) e Salomão (1999)

*Em solos hidromórficos a suscetibilidade continuará a mesma indicada nas classes preliminares, independentemente do nível de erosividade, por constituírem solos não suscetíveis à erosão.

A sobreposição dos dados aos valores de comprimento das encostas foi realizada com o intuito de uma verificação na delimitação das áreas de suscetibilidade encontradas, possibilitando a elaboração do mapa final. Ressalta-se que quanto maior for o comprimento das encostas, mais intensa será a ocorrência da erosão. Sendo assim, os valores mais 
elevados de comprimento foram associados a uma maior suscetibilidade e os menos elevados a uma menor suscetibilidade.

Para a qualificação da suscetibilidade seguiu-se como critério a definição das cinco classes descritas por Salomão (1999), estando estas compatibilizadas com as classes de capacidade de uso dos solos (LEPSCH et al., 1983), destacadas a seguir:

- Classe I: Extremamente Suscetível - onde os terrenos apresentam problemas complexos de conservação, indicados para preservação ou para reflorestamento.

- Classe II: Muito Suscetível - onde os terrenos apresentam problemas complexos de conservação, parcialmente favoráveis à ocupação por pastagens, sendo mais apropriados para reflorestamento.

- Classe III: Moderadamente Suscetível - onde os terrenos apresentam problemas complexos de conservação, sendo mais indicados a pastagens e culturas perenes.

- Classe IV: Pouco Suscetível - onde os terrenos apresentam problemas complexos de conservação, sendo mais indicados a pastagens e culturas perenes e, eventualmente, a culturas anuais, porém exigindo práticas mecanizadas de controle da erosão.

- Classe V: Pouco a não Suscetível - corresponde aos terrenos sem problemas especiais de conservação, podendo ser utilizados com qualquer tipo de cultura; a terrenos com problemas simples de conservação, podendo também serem utilizados com qualquer tipo de cultura, porém exigindo práticas não mecanizadas de controle da erosão; e a terrenos sem problemas de conservação, mas exigindo técnicas especiais de cultivo, por se constituírem de solos encharcados.

\section{RESULTADOS E DISCUSSÃO}

\section{Erosividade das chuvas}

A erosividade das chuvas foi calculada através de dados de precipitação disponibilizados no portal HidroWeb da ANA. Para tal, foram analisados dados pluviométricos de cinco estações localizadas próximo ao local estudado, sendo estas: Fazenda Letreiro (estação 1), Fazenda Paraíso (estação 2), Fazenda Nossa Senhora Aparecida (estação 3), Monte Alegre de Minas (estação 4) e Xapetuba (estação 5).

A análise dos dados de precipitação coletados demonstra uma distribuição irregular das chuvas durante os meses do ano, indicando uma maior pluviosidade nos meses de outubro a março, característica inerente ao clima tipicamente tropical (gráfico 1). 
As médias anuais de precipitação, pelos dados coletados, variam de 1346,7 a 1537,1 $\mathrm{mm}$, confirmando as médias comuns para a região. Verificou-se, desta forma, uma amplitude de 190,4 mm para os totais anuais de precipitação entre as estações pluviométricas utilizadas, evidenciando a dinâmica da entrada de água no sistema hidrológico da área analisada (Tabela 6).

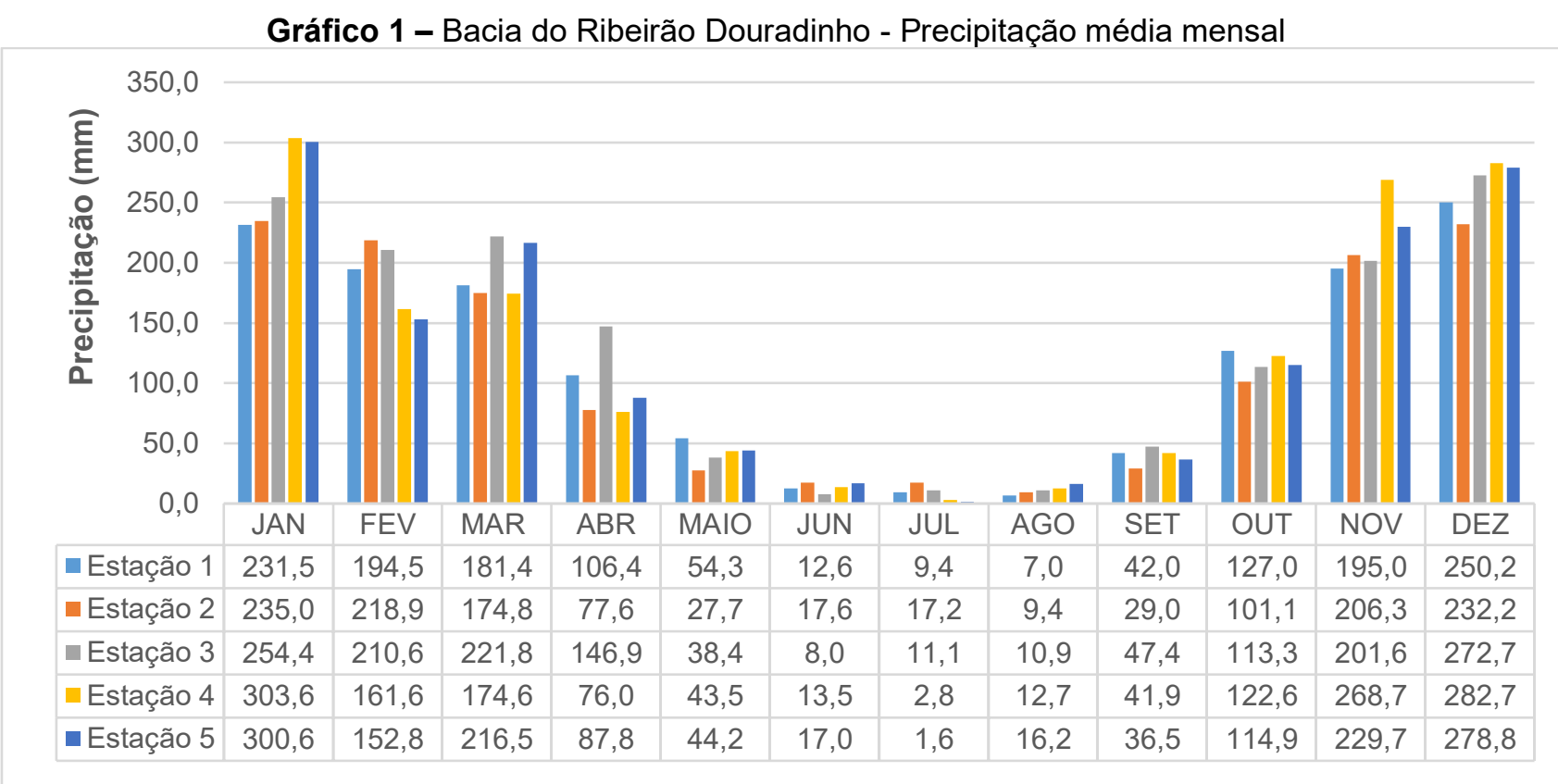

Fonte: HidroWeb/ANA (2019). Org.: Autores (2020)

Tabela 6 - Critério para a definição das classes finais de suscetibilidade à erosão laminar

\begin{tabular}{cc}
\hline \multicolumn{2}{c}{ Média anual (mm) } \\
\hline Estação 1 & 1411,2 \\
Estação 2 & 1346,7 \\
Estação 3 & 1537,1 \\
Estação 4 & 1504,1 \\
Estação 5 & 1496,7 \\
\hline Fonte: HidroWeb/ANA (2019). Org.: Autores (2020)
\end{tabular}

A espacialização da precipitação foi realizada através da interpolação dos dados supracitados pelo método Inverse distance weighted (IDW). Os valores médios anuais de precipitação variam entre 1364 e 1487 mm (Figura 4).

Em relação à erosividade, ressalta-se que esta foi determinada com base na equação estabelecida por Bertoni e Lombardi Neto (1993). Seus valores estão diretamente relacionados aos de precipitação, uma vez que em seu cálculo são utilizados os dados referentes às médias pluviométricas mensais e anuais. 
Desta forma, observa-se que para as estações analisadas os meses com os maiores valores de erosividade correspondem também aos meses mais chuvosos (novembro a março), enquanto os menores aos meses menos chuvosos (abril a outubro), (gráfico 2).

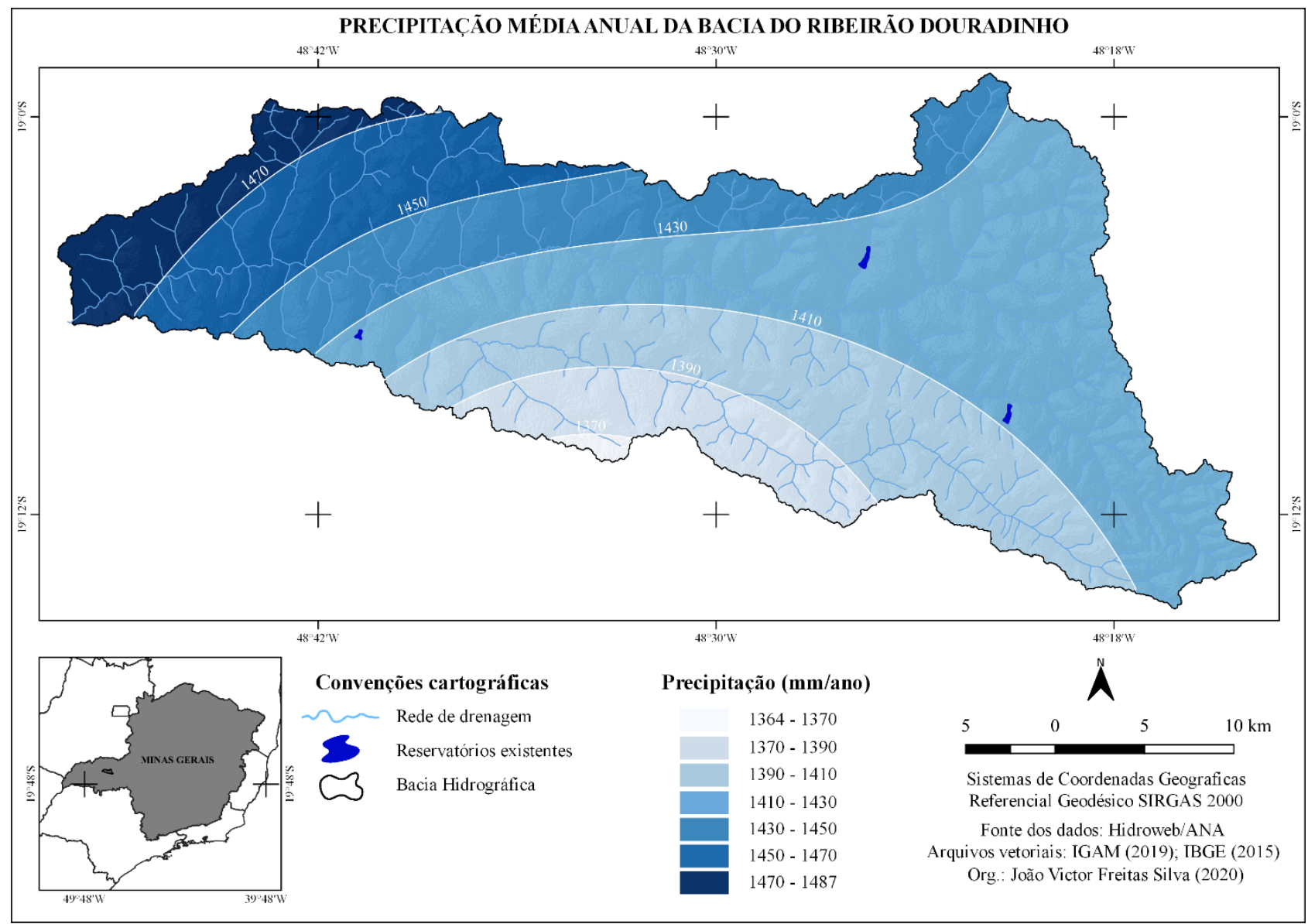

Figura 3 - Precipitação média anual da bacia do Ribeirão Douradinho Org.: Autores, 2020.

Gráfico 2 - Bacia do Ribeirão Douradinho - Precipitação média mensal

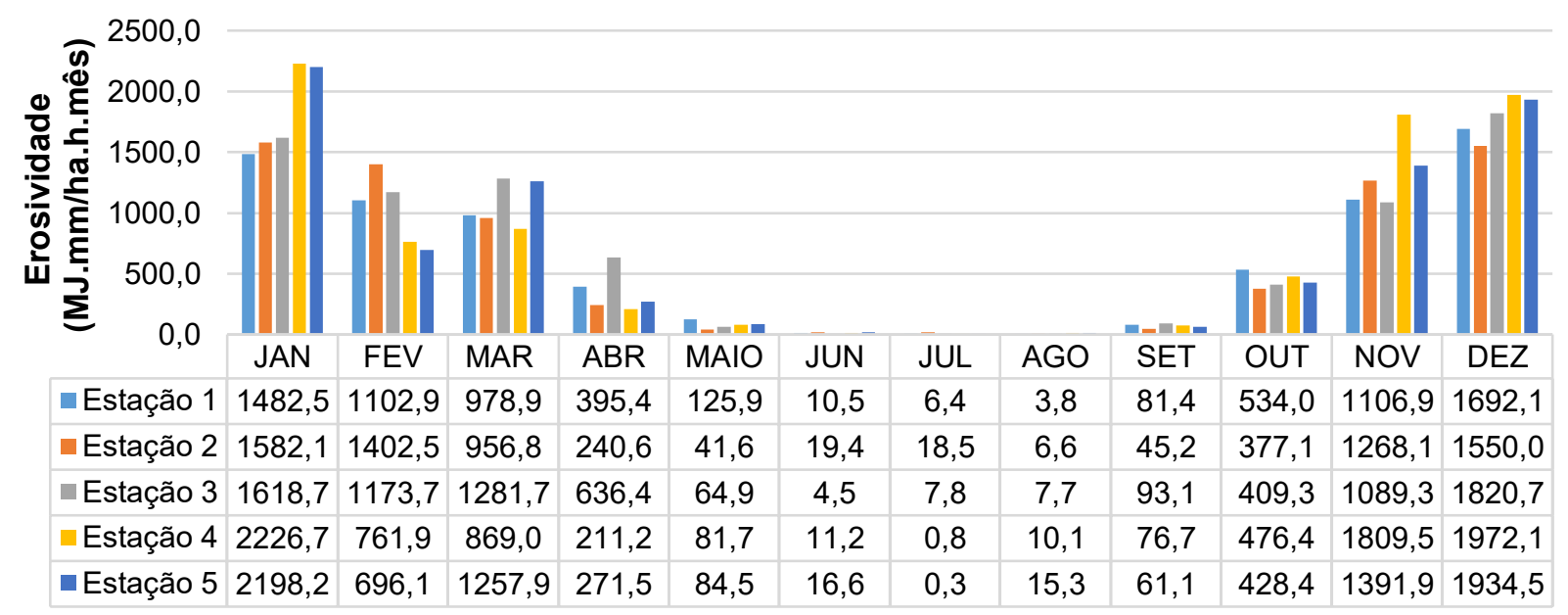

Fonte: HidroWeb/ANA (2019). Org.: Autores (2020). 
Os valores anuais de erosividade para as estações variam de 7508,5 a 8507,3 MJ.mm/ha.h.ano, com uma amplitude de 998,8 MJ.mm/ha.h.ano (Tabela 7). Para a área da bacia estes valores variam entre 7593 a 8223 MJ.mm/ha.h.ano e são classificados, segundo Carvalho (2008), como fortes (Figura 5).

Tabela 7 - Critério para a definição das classes finais de suscetibilidade à erosão laminar

\section{Erosividade anual (MJ.mm/ha.h.ano)}

\begin{tabular}{ll}
\hline Estação 1 & 7520,8 \\
\hline Estação 2 & 7508,5 \\
Estação 3 & 8207,8 \\
Estação 4 & 8507,3 \\
Estação 5 & 8356,4 \\
\hline
\end{tabular}

Org.: Autores (2020).

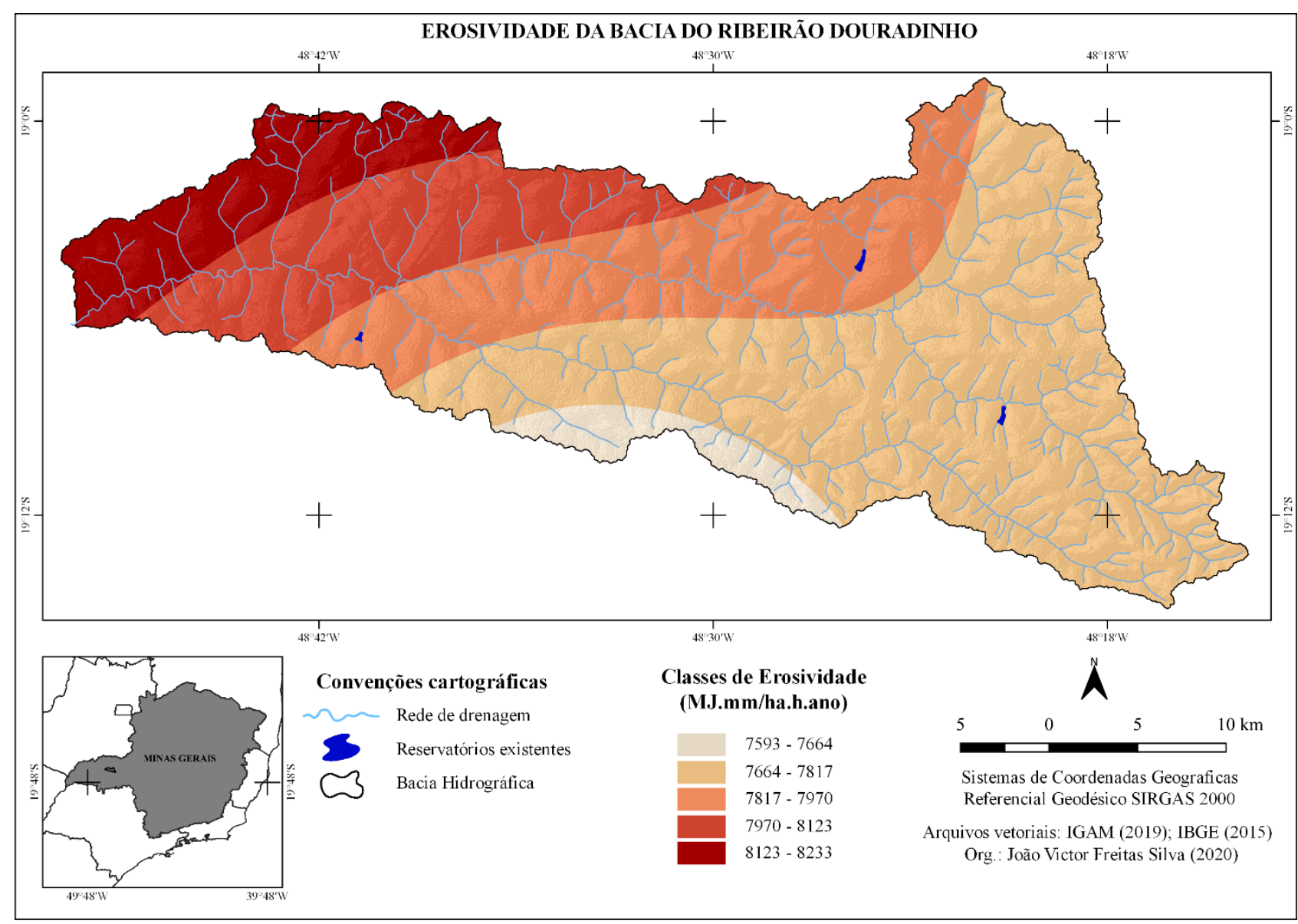

Figura 4 - Erosividade anual da bacia do Ribeirão Douradinho

Org.: Autores, 2020. 


\section{Erodibilidade dos solos}

Os dados de erodibilidade para a bacia do Ribeirão Douradinho (Figura 5) foram obtidos através da comparação e associação de diferentes valores encontrados na literatura a respeito do tema, de locais caracterizados por possuírem tipos pedológicos semelhantes aos da área em questão, e qualificados com base na classificação proposta por Mannigel et al. (2002), (Tabela 8).

Tabela 8 -Classificação da erodibilidade dos solos

\begin{tabular}{cc}
\hline Classificação & Erodibilidade (t.ha.h/ha.MJ.mm) \\
\hline Extremamente alta & $>0,0600$ \\
\hline Muito alta & $0,0450-0,0600$ \\
\hline Alta & $0,0300-0,0450$ \\
\hline Média & $0,0150-0,0300$ \\
\hline Baixa & $0,0090-0,0150$ \\
\hline Muito baixa & $<0,0090$ \\
\hline \multicolumn{2}{c}{ Fonte: Mannigel et al (2002) } \\
\hline
\end{tabular}

Desta Forma, optou-se por dados que foram estabelecidos através de um mesmo método, possibilitando uma maior compatibilidade entre os resultados. Ressalta-se que na área de estudos estão presentes os tipos pedológicos pertencentes à ordem dos Latossolos (L) e Argissolos (P), sendo a sua erodibilidade estabelecida de acordo com o primeiro elemento da associação (Tabela 9).

Tabela 9 - Bacia do ribeirão Douradinho - Erodibilidade dos solos

Solos

LVd - Latossolos Vermelhos Distróficos

LVdf - Latossolos Vermelhos Distroférricos

LVAd - Latossolos Vermelho-amarelo Distrófico

LVw - Latossolo Vermelho Ácrico

PVAd - Argissolo Vermelho-Amarelo Distrófico

PVAe - Argissolo Vermelho-Amarelo Eutrófico
Erodibilidade (t.ha.h/ha.MJ.mm)

0,0061

0,0071

0,0112

0,0263

0,0466

0,0540

Fonte: Mannigel et al. (2002) Org.: Autores, 2020.

A classe dos Latossolos apresenta, de modo geral, pouca erodibilidade. A sua localização em áreas pouco declivosas confere ao solo uma baixa suscetibilidade frente aos processos de desagregação de sua estrutura (PEREIRA, 2014). Segundo Lepsch (2010) os Latossolos em áreas aplainadas possuem um boa drenagem e capacidade de retenção. Nesse sentido apresentam maior resistência em relação ao processo de erosão laminar. 
De acordo com a classificação de Mannigel et al. (2002), os Latossolos encontrados na área da bacia inserem-se nas classes de erodibilidade de muito baixa a média, com valores de 0,0061 para o Latossolo Vermelhos Distrófico, 0,0071 para o Latossolo Vermelho Distroférrico, 0,0112 para o Latossolo Vermelho-amarelo Distrófico e 0,0263 para o Latossolo Vermelho Ácrico.

A classe dos Argissolos apresenta uma menor estabilidade dos seus agregados devido a sua constituição granulométrica. Estes solos são mais propensos à erosão, principalmente pela baixa resistência ao desprendimento de suas partículas durante eventos pluviométricos intensos. $\mathrm{O}$ aumento de argila em profundidade e o horizonte superficial arenoso atribuem a esse tipo de solo maiores valores de erodibilidade (PEREIRA, 2014).

Os Argissolos encontrados na área de estudo são classificados como de erodibilidade muito alta, apresentando valores de 0,0466 para o Argissolo Vermelho-Amarelo Distrófico e 0,0540 para o Argissolo Vermelho-Amarelo Eutrófico.

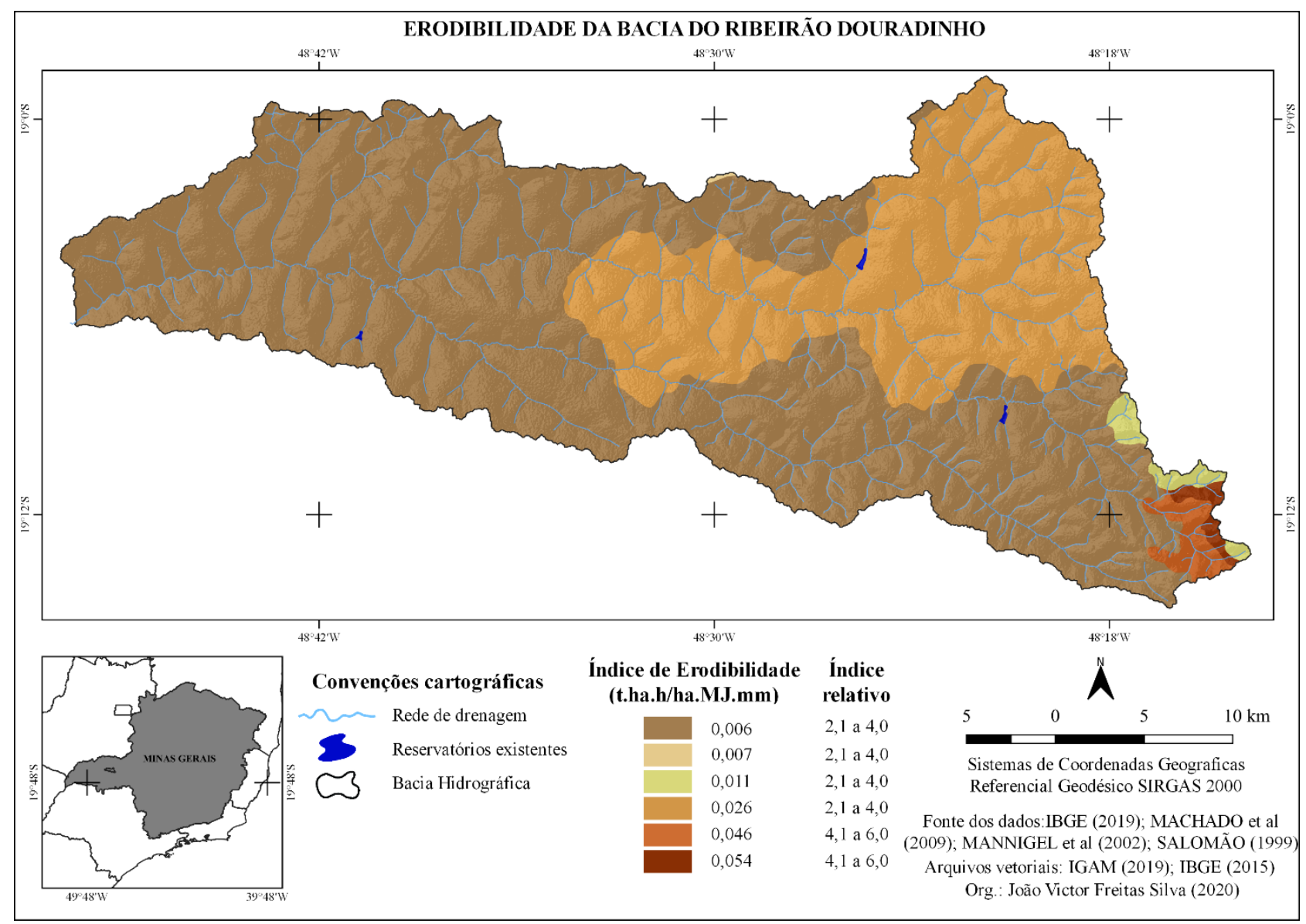

Figura 5 - Erodibilidade anual da bacia do Ribeirão Douradinho

Org.: Autores, 2020. 
Na relativização apresentada por Salomão (1999), a fim de proporcionar o cruzamento dos dados, a erodibilidade dos solos na bacia estudada apresenta-se entre os índices relativos de 2,1 a 4,0, pertencente à classe IV (Latossolos de textura média, Latossolos de textura argilosa, Terra Roxa Estruturada) e de 4,1 a 6,0, pertencente à classe III (Podzólicos de textura argilosa). Os valores referentes às classes deste fator foram espacializados na Figura 5.

\section{Declividade do terreno}

$\mathrm{Na}$ bacia os valores de declividade variam entre 0 e $20 \%$, sendo mais representativos os valores pertencentes às categorias entre 0 e $6 \%$ (correspondente a $60,01 \%$ da área da bacia) e entre 6 e 12\% (correspondente a 32,97\% da área da bacia). Os valores mais elevados encontrados na bacia, entre 12 e $20 \%$ (correspondente a $7,01 \%$ da área estudada), estão concentrados nas nascentes do Ribeirão Água Limpa e ao longo dos canais fluviais.

Os valores em $\mathrm{km}^{2}$ para cada uma das categorias podem ser observados na Tabela 10. Segundo a classificação proposta por Salomão (1999) as categorias de declividade presentes na bacia correspondem à classe IV (menores que 6\%), classe III (de 6 a 12\%) e à classe II (de 12 a 20\%). No mapa a seguir encontram-se espacializadas as referidas categorias de declividade (Figura 7).

Tabela 10 - Bacia do ribeirão Douradinho - Erodibilidade dos solos

\begin{tabular}{ccc}
\hline Categoria & Área em $\mathbf{~ k m}^{\mathbf{2}}$ & Área em \% \\
\hline $0-6 \%$ & 553,46 & 60,01 \\
\hline $6-12 \%$ & 304,04 & 32,97 \\
\hline $12-20 \%$ & 64,66 & 7,01 \\
\hline
\end{tabular}

Org.: Autores, 2020. 


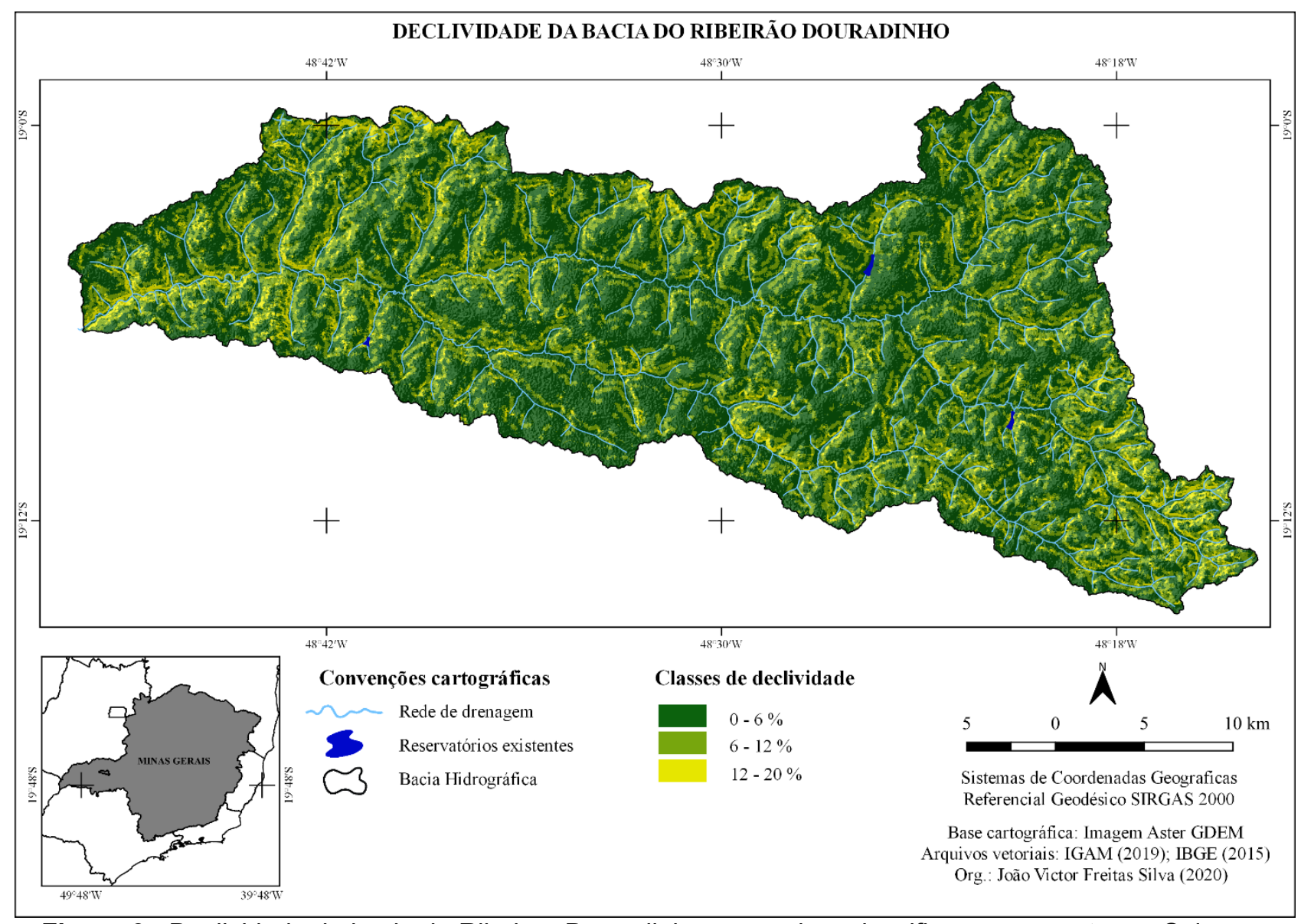

Figura 6 - Declividade da bacia do Ribeirão Douradinho, segundo a classificação proposta por Salomão (1999). Org.: Autores, 2020.

O mapa em questão contribui para o claro entendimento da dinâmica dos processos erosivos atuantes nos diferentes setores da bacia.

\section{Comprimento das encostas}

$\mathrm{Na}$ bacia do Ribeirão Douradinho os valores de comprimento médio das encostas variam entre 75 e $1175 \mathrm{~m}$. Os mais representativos correspondem às categorias de 75 a 175 m (15,96\% da área da bacia) e 475 a 575 m (15,19\% da área da bacia) (Figura 8).

O comprimento das encostas refere-se à distância em metros do ponto de origem do caimento da água até um canal definido ou até um determinado local que favoreça a deposição dos sedimentos, indicando o caminho a ser percorrido pelas águas pluviais em uma bacia hidrográfica de montante a jusante (RENARD et al., 1997). Juntamente com a declividade, o comprimento das encostas torna-se uma variável significativa para os estudos sobre erosão dos solos. 


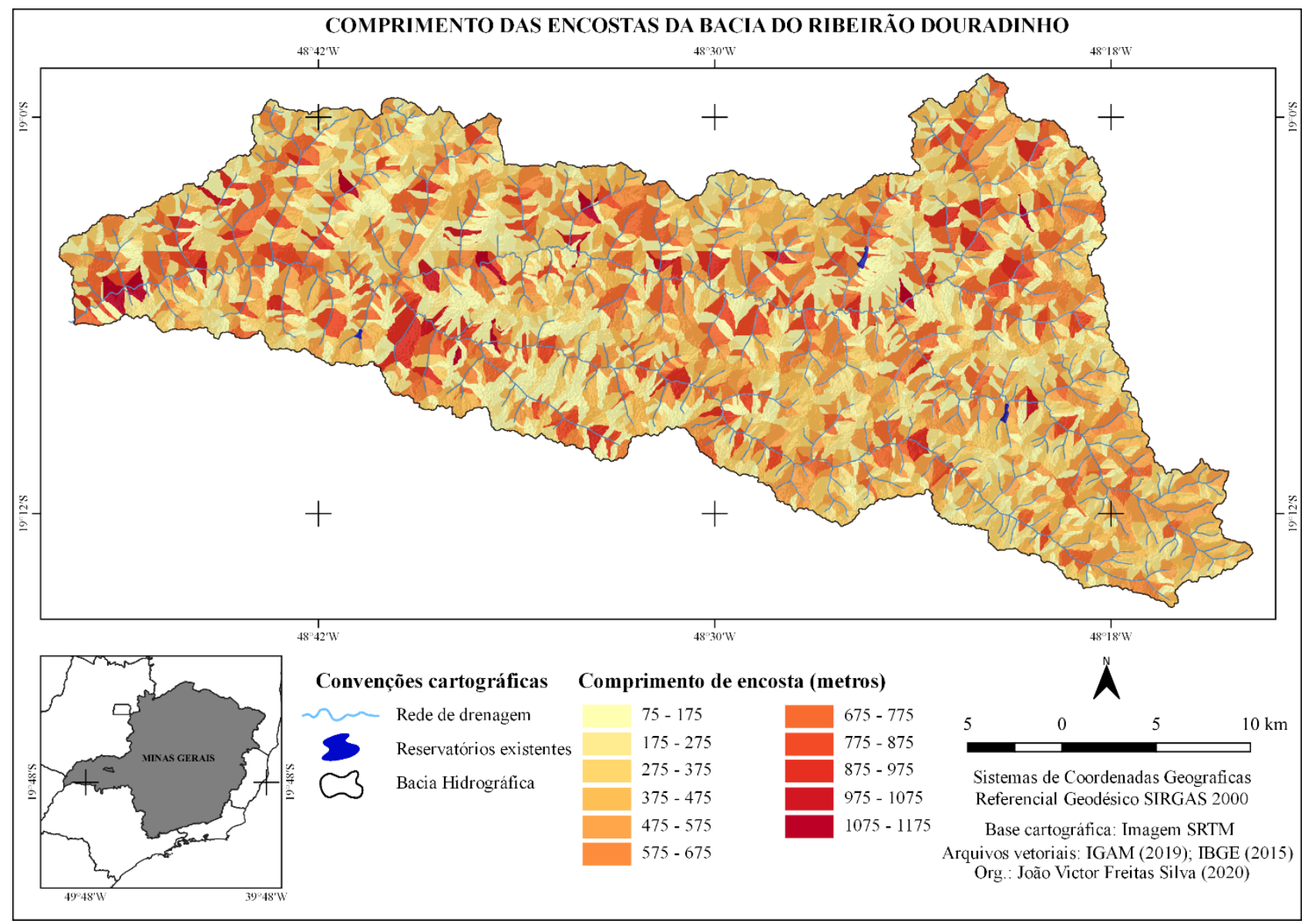

Figura 7 - Comprimento das encostas da bacia do Ribeirão Douradinho

Org.: Autores, 2020.

\section{Suscetibilidade à erosão laminar}

$\mathrm{Na}$ bacia em questão a integração das informações relativas aos fatores de ordem natural resultou em três diferentes classes de suscetibilidade à erosão laminar, sendo estas: muito suscetível (II), moderadamente suscetível (III) e pouco suscetível (IV). Os valores em $\mathrm{km}^{2}$ e em porcentagem para cada uma das classes de suscetibilidade podem ser observados na Tabela 11 a seguir.

Tabela 11 - Bacia do Ribeirão Douradinho - Distribuição das classes de suscetibilidade em $\mathrm{km}^{2} \mathrm{e}$ porcentagem

\begin{tabular}{ccc}
\hline Categoria & Área $\mathbf{~ e m ~} \mathbf{~ k m}^{\mathbf{2}}$ & Área em \% \\
\hline Muito suscetível & 163,37 & 17,73 \\
\hline Moderadamente suscetível & 434,02 & 47,06 \\
\hline Pouco suscetível & 324,77 & 35,21 \\
\hline
\end{tabular}

Org.: Autores, 2020.

Na Figura 8 é possível observar a distribuição das classes de suscetibilidade na área de estudo. 


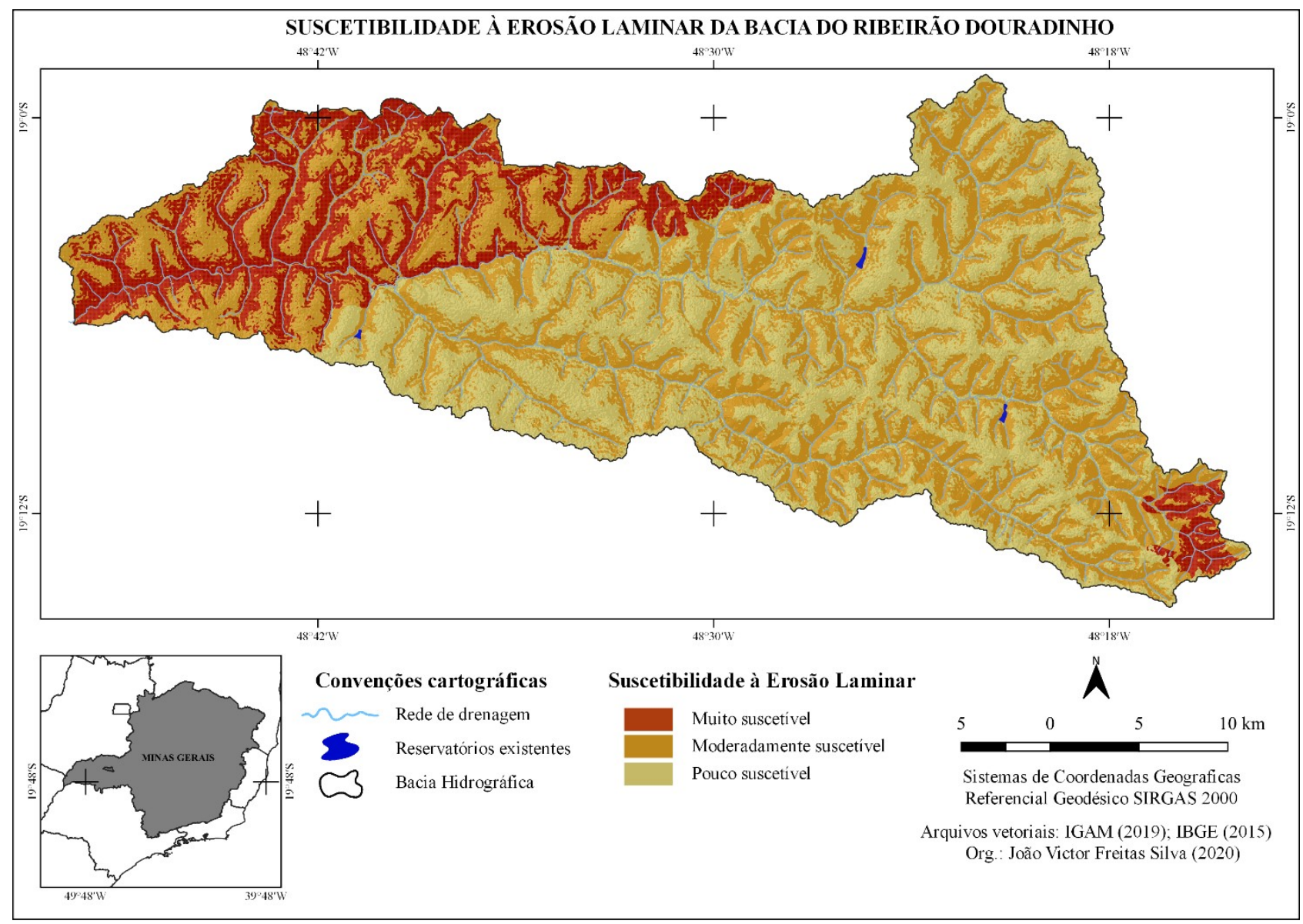

Figura 9 - Suscetibilidade à erosão laminar da bacia do Ribeirão Douradinho

Org.: Autores, 2020.

A classe II, muito suscetível, com já citado anteriormente, corresponde a terrenos que apresentam problemas complexos de conservação. Nas áreas correspondentes a esta categoria de suscetibilidade a ocupação por pastagens é apenas parcialmente favorável, sendo mais apropriadas as atividades voltadas ao reflorestamento (SALOMÃO, 1999).

Esta classe é encontrada, em maior expressividade, no médio e baixo curso e em áreas situadas próximas às nascentes do Ribeirão Água Limpa. Ocorrem em solos do tipo Latossolo, em declividades de 6 a 20\%, nas categorias de erosividade com os valores acima de 7970 MJ.mm/ha.h.ano e nos Argissolos, em declividades de 6 a 20\%, nas erosividades abaixo de 7970 MJ.mm/ha.h.ano.

A classe III, moderadamente suscetível, corresponde também a terrenos com problemas complexos de conservação. Tais áreas são mais indicadas apenas para pastagens e culturas perenes (SALOMÃO, 1999).

$\mathrm{Na}$ bacia, esta classe encontra-se distribuída em todos os seus compartimentos, quase sempre associada a solos do tipo Latossolo em declividades de 0 a $6 \%$, onde a erosividade apresenta valores acima de 7970 MJ.mm/ha.h.ano, e em declividades de 6 a 
$20 \%$ nas categorias de erosividade com valores abaixo de 7970 MJ.mm/ha.h.ano. Aparece também em solos do tipo Argissolo, em declividades de 0 a $6 \%$, nas erosividades abaixo de 7970 MJ.mm/ha.h.ano.

A classe IV, pouco suscetível, apresenta os mesmos problemas das classes citadas anteriormente, porém, de acordo com a sua compatibilização às classes de capacidade de uso dos solos, seus terrenos são indicados para pastagens e culturas perenes sendo, eventualmente, indicado para o cultivo de culturas anuais, exigindo, nestes casos, práticas mecanizadas de controlo da erosão (SALOMÃO, 1999).

Esta classe encontra-se distribuída no alto e médio curso da área de estudo e compreende solos do tipo Latossolo, em declividades de 0 a $6 \%$, em categorias de erosividade com valores abaixo de 7970 MJ.mm/ha.h.ano.

Em síntese, pode-se constatar que quase metade da área da bacia apresenta suscetibilidade moderada que, quando somada às áreas muito suscetíveis, alcançam aproximadamente $65 \%$ da área total. Segundo dados apresentados por Rosa (1995) as perdas naturais de solo por erosão laminar na bacia do Ribeirão Douradinho variam entre 285 e 570 ton $/ \mathrm{km}^{2} / \mathrm{ano}$.

\section{CONCLUSÕES}

Compreender a origem, a atuação e a evolução da erosão nos terrenos e os impactos ambientais dela advindos é o primeiro passo para a determinação de medidas mitigadoras e para a aplicação de práticas de conservação e/ou recuperação dos solos e do meio ambiente como um todo. Nesse sentido, o presente trabalho apresentou um diagnóstico a respeito da suscetibilidade erosiva dos solos da bacia hidrográfica do Ribeirão Douradinho em relação ao processo de erosão laminar.

A erosão laminar ocasiona a perda das camadas superficiais mais férteis dos solos, acarretando a redução da produtividade agrícola, no aumento dos custos de produção, numa maior demanda por insumos, além de diversos impactos negativos que afetam diretamente e/ou indiretamente o ambiente.

No que diz respeito à suscetibilidade à erosão laminar na bacia do Ribeirão Douradinho, determinada a partir da integração das informações de ordem natural correspondentes à erosividade das chuvas, à erodibilidade dos solos, à declividade do terreno e ao comprimento das encostas, concluiu-se que $64,79 \%$ dos terrenos da área estudada estão entre as classes de moderada a muito suscetível, correspondendo a solos 
com alta vulnerabilidade em relação ao desenvolvimento dos processos erosivos. De acordo com Salomão (1999), esses terrenos apresentam problemas complexos de conservação, e são favoráveis ou parcialmente favoráveis a ocupações por pastagem e culturas perenes, sendo mais apropriados às atividades voltadas ao reflorestamento.

\section{REFERÊNCIAS}

AGÊNCIA NACIONAL DE ÁGUAS (ANA). HidroWeb: Séries históricas. Disponível em: <http://www.snirh.gov.br/hidroweb/serieshistoricas>. Acesso em: 30 de mar. 2020.

BERTONI, J.; LOMBARDI NETO, F. Conservação do Solo. $3^{a}$ edição, São Paulo: Editora Ícone, 1993.

CARVALHO, N. O. Hidrossedimentologia Prática. 2a ed. Rio de Janeiro: Interciência, 2008.

INSTITUTO BRASILEIRO DE GEOGRAFIA E ESTATÍSTICA (IBGE). Geociências: Informações ambientais. Disponível em: <https://www.ibge.gov.br/geociencias/downloadsgeociencias.html>. Acesso em: 25 de mar. 2020.

INSTITUTO DE PESQUISAS TECNOLÓGICAS DO ESTADO DE SÃO PAULO. Orientações para o combate à erosão no estado de São Paulo, Bacia do Pardo Grande. São Paulo: IPT, v.3. 1990.

INSTITUTO NACIONAL DE PESQUISAS ESPACIAIS (INPE). Topodata: Banco de dados geomorfométricos do Brasil. Mapa índice. Disponível em: <http://www.dsr.inpe.br/topodata/>. Acesso em: 31 de mar. 2020.

INSTITUTO MINEIRO DE GESTÃO DAS ÁGUAS (IGAM). Base cartográficas digitais: Hidrografia. Disponível em: < http://www.igam.mg.gov.br/banco-de-noticias/1-ultimasnoticias/1312-hidrografia>. Acesso em: 27 de mar. 2020.

LEPSCH, I. F. Formação e conservação dos solos. 2.ed. Oficina de Texto, São Paulo, 2010. 216 p.

LEPSCH, I. F. et al. Manual para levantamento utilitário do meio físico e classificação de terras no sistema de capacidade de uso. $4^{a}$ aproximação. Campinas: Sociedade Brasileira de Ciências do solo, 1983.

MACHADO, M. L. et al. Levantamento sistemático dos fatores da Equação Universal de Perdas de Solos (USLE) para o delineamento de áreas com potencial erosivo da bacia PN1 - IGAM, Minas Gerais (resultados parciais). Anais XIV Simpósio Brasileiro de Sensoriamento Remoto. Natal, 2009, p. 7733-7739.

MANNIGEL, A. R. et al. Fator erodibilidade e tolerância de perda de solos do Estado de São Paulo. Acta Scientiarum. p. 1335 - 1340, v. 24, n. 5. Maringá. 2002. DOI: https://doi.org/10.4025/actasciagron.v24i0.2374 
OLIVEIRA, V. C. V. Suscetibilidade e risco à erosão laminar no setor sul do altocurso da bacia do rio Araguaia (GO/MT): discussão metodológica e proposta de avaliação espacial. Dissertação de mestrado. Goiânia, 2004.

PEREIRA, J. S. Avaliação das perdas de solos por erosão laminar na área de influência da UHE Amador Aguiar I. 2014. 167 f. Dissertação de mestrado. Universidade Federal de Uberlândia - UFU, Uberlândia, 2014.

RENARD, K. G. et al. Predicting soil erosion by water: a guide to conservation planning with the Revised Universal Soil Loss Equation (RUSLE). Washington, 1997: Agriculture Handbook, n. $703 . \quad$ Dispinível em: <https://www.tucson.ars.ag.gov/unit/publications/PDFfiles/1132.pdf>. Acesso em: 09 de out 2020.

SALOMÃO, F. X. T. Controle e prevenção dos processos erosivos. In: GUERRA, A. J. T.; SILVA, A. S.; BOTELHO R. G. M. (orgs.). Erosão e conservação dos solos: conceitos temas e aplicações. Rio de Janeiro: Bertrand Brasil, cap. 7. 1999, p. 229-267.

TERRACLASS. Mapeamento do uso e cobertura da terra do Cerrado. Projeto TerraClass Cerrado 2013. Brasília-DF, 2015. 69 p.

VILLELA, S. M. MATTOS, A. Hidrologia Aplicada. São Paulo, MacGraw Hill do Brasil, 1975. 247p. 